\title{
Examining the Presence of Symmetry within Acheulean Handaxes: A Case Study in the British Palaeolithic
}

\author{
James Cole
}

\begin{abstract}
This paper examines the relationship between the presence of symmetry and the Acheulean biface within a predominantly British Lower Palaeolithic context. There has been a long-standing notion within Palaeolithic studies that Acheulean handaxes are predominantly symmetrical and become increasingly so as time progress as a reflection of increasing hominin cognitive and behavioural complexity. Specifically, the presence of symmetry within Acheulean handaxes is often seen as one of the first examples of material culture being used to mediate social relationships. However, this notion has never been satisfactorily tested against a large data set. This paper seeks to address the issue by conducting an analysis of some 2680 bifaces across a chronological and geographical span. The results from the sample presented here are that symmetrical bifaces do not appear to have a particularly strong presence in any assemblage and do not appear to increase as time progress. These results have significant implications for modern researchers assessing the cognitive and behavioural complexities of Acheulean hominins.
\end{abstract}

\section{Introduction}

Over 200 years have passed since the first recorded discovery of a handaxe was noted by Frere (1800) and more than 150 since the great antiquity of these artefacts was fully recognized (Gamble \& Kruszynski 2009). Yet to a large extent the functions of the handaxe remain unclear, given this is an artefact that spans almost 2 million years (Lepre et al. 2011; Machin 2009), and at least three species of hominin - Homo ergaster/erectus, Homo heidelbergensis and Homo neanderthalensis (McNabb 2013). Furthermore, the great interest and fascination of the handaxe by modern researchers is reflected in the sheer amount of academic discourse and literature devoted to the understanding of this artefact over the last few decades (Ashton \& McNabb 1994; Cole 2011; 2015; Gamble 1998; Gowlett 2011; Hardaker \& Dunn 2005; Hodgson 2015; Hopkinson \& White 2005; Iovita \& McPherron 2011; Kohn \& Mithen 1999; Machin 2009; Machin et al. 2007; Marshall et al. 2002; McNabb 2013; McNabb et al. 2004; McPherron 1999; 2000; Pope et al. 2006; Porr 2005; Ronen 1982; Saragusti et al. 1998; Spikins 2012; Toth 1990; Wenban-Smith 2004; White 1998a,b; Wynn 1995). Similarly, the reasonable interpretations of the handaxe range from practical tools relating to butchery, mechanisms of sexual selection, aesthetic markers, cultural mediators and objects used to negotiate the landscapes and socialscapes of the Acheulean world. This range of interpretation reflects the complexity of understanding an artefact that, at first glance, looks the same in general shape and size, yet is made by three distinct non-human species for more than a million years where there cannot possible be a 'one interpretation fits all' scenario.

So the question arises as to why the handaxe has formed such a focus of debate amongst those interested in the Palaeolithic? The answer lies in the notion that the handaxe is seen to represent the first tools shaped through deliberate attention to form (Iovita \& McPherron 2011; Wynn 2004), corresponding to a significant shift in behaviour and cognition from the non-handaxe industries such as the Oldowan and Clactonian (in Europe) (McNabb 2007; 2013; White 2000). The poor preservation of organic artefacts (for exceptions, see Thieme 1997; 2005; Warren 1911) from such deep antiquity therefore means that the main focus for hominin behaviour of the Pleistocene lies with stone tools. It has already been recognized that lithic tool production reflects varying degrees of planning, problem solving, perceptual-motor co-ordination and sociality (Stout \& Chaminade 2009) and therefore the analyses of lithic 
artefacts can allow a route through which modern researchers may attempt to access the cognitive and behavioural practices of the hominin ancestors who made the stone tools.

The attention to handaxe form is further perceived to be related to a behavioural standardization in artefact morphology associated with agreed cultural practice within hominin societies (Kohn \& Mithen 1999; McNabb et al. 2004; Mellars 1989; 1991; Monnier 2006; Ronen 1982; Saragusti et al. 1998; Stout \& Chaminade 2009; Wenban-Smith 2004) - although see Chase (1991) for discussions against. The argument defending this position is as follows: the higher the degree of standardization and deliberate imposition of shape and form within handaxe morphology, the higher the influence social learning plays on the formation of lithic tools (McNabb et al. 2004; Monnier 2006). Standardization in artefact morphology is seen to represent a desired end product in accordance with socially defined or accepted parameters which in turn are the consequence of mental categories which may be representative in nature (Monnier 2006). The presence of symmetry within Acheulean biface morphology is often seen to represent the epitome of the standardized handaxe, present throughout Acheulean assemblages and increasing significantly in occurrence through the Acheulean as time progresses (Hodgson 2009; 2015; Saragusti et al. 1998). Hodgson (2015) proposes two main sides to the handaxe symmetry debate:

1) symmetry can be explained by functional constraints, or that there is little evidence to support a trend toward symmetry within the Acheulean record (Cole 2015; McNabb 2013; McNabb et al. 2004; McPherron 2009);

2) symmetry is important to understanding human behaviour (important to note here that this is never disputed by the previous authors) and becomes increasingly prominent within Acheulean handaxes through time (Ambrose 2001; Hodgson 2009; 2015; Saragusti et al. 1998; 2005).

Therefore, one of the key research questions regarding the Acheulean biface is whether they were purely functional in design, or whether they were imbued with significant cultural meaning where the imposition of symmetry represents a clear attention to standardized form imposition involving a strong and distinct social signal that increases significantly as time progresses. In other words, discussions of handaxe symmetry have implications that go far beyond the physical or cognitive demands reflected through chaîne opératoire or façonnage, but are crucial to our understanding and identification of when material culture began to play an active role in mediating hominin social relationships through an agreed cultural norm (Cole 2014a; 2015).

This paper seeks to make a contribution to the continuing Acheulean handaxe debate by presenting an analysis of Acheulean bifaces, encompassing some 2680 artefacts. The main focus of this paper will be to elucidate a number of key assumptions held within the wider academic community in regard to the presence of symmetrical form within Acheulean handaxe morphology:

- $\quad$ Acheulean handaxes are often made to a symmetrical mental template.

- Symmetrical handaxes are present in large quantities throughout Acheulean assemblages.

- $\quad$ The presence of symmetrical handaxes within Acheulean assemblages increases through time as a marker of increasing hominin cognitive ability.

Versions of the three statements given above appear time and time again throughout the literature on the Acheulean handaxe debate; however, there is very little published by which these statements are substantiated. This is in part due to the fact that many of the behavioural interpretations regarding Acheulean symmetry are based on small and selected datasets (e.g. Saragusti et al. 1998), whereas the current study presents for the first time a multiple assemblage-wide analysis on a larger sample of data in an attempt to redress this imbalance. In addition, following McNabb et al. (2004), the analysis examines the evidence for the presence of regularity and repetitive patterning within the Acheulean assemblages presented, 
concentrating on outline shape and manufacture in order to explore the notion that cultural influence should play a significant role in determining biface morphology if there is a degree of standardization and regularity in what was made. This paper is designed to engage and facilitate debate amongst researchers interested in human origins. It is not an overt criticism of other methodologies or behavioural interpretations, but more of a call to ensure that we are not taking assumed and largely untested behavioural norms for granted within our interpretations of hominin behaviour.

\section{Sites and methodology}

The methodological level of analysis followed within this paper (based on the results presented in Cole 2011) is a high-level regional overview aimed at identifying hominin behavioural traits at a species level. It is hoped that general trends in hominin behaviour will overprint any local quirks in the archaeological record (Gamble 1996; 1998). However, discussions on standardization (epitomized through the presence of symmetry) within assemblages should acknowledge the presence of apparent 'short-lived' episodes of artefact standardization such as those seen within the handaxe pairs at Boxgrove or Foxhall Road (Hopkinson \& White 2005; Pope et al. 2006; White \& Plunkett 2004).

\section{Samples}

Artefacts from a total of 11 sites were examined and recorded (Fig. 1): nine of the sites were located within the British Isles, one site (Et Tabun) in the Middle East and a further site (the Cave of Hearths) in South Africa.

\section{<FIGURE 1 NEAR HERE>}

Figure 1: Location map showing case study sites.

The sites and assemblages were chosen in order to reflect a regional case study (the British Isles) reflecting a chronological pattern of occupation, to allow an inter-site comparison across time. This was done to test whether evidence for artefact standardization and symmetry presence increased or not. The Cave of Hearths and Et Tabun were chosen as external comparative sites (completely separate from the regional study area), where hominin behaviour on a species level could be broadly related to the patterns reflected within the British Isles data. The Cave of Hearths seemed an appropriate choice, as it was one of the sites analysed within the original McNabb et al. (2004) paper where the methodology was first reviewed, and represents an Acheulean site from the opposite end of the Acheulean world to the sites examined from the British Isles. Et Tabun (Layers F, Ea-Ed and D) represents a site of almost continuous occupation from the Lower to Middle Palaeolithic and therefore it was thought that the sample would allow for an interesting comparison to the regional scale offered by the British Isles data. The sites span a range of dates from Marine Isotope Stages (MIS) 15 to 3 (Table 1), stretching from the Lower to Middle Palaeolithic.

\section{<TABLE 1 NEAR HERE>}

\section{Methodology}

The methods of handaxe analysis (tip shape, secondary working, symmetry and edge working) follow the methodology described by McNabb et al. (2004) and McNabb and Sinclair (2009) (Fig. 2), and are used to examine the archaeological record from a broad behavioural 
perspective. From such a platform it will be possible for future work to examine and test the conclusions drawn here against more in-depth and site-specific behavioural models.

\section{<FIGURE 2 NEAR HERE>}

Figure 2: Illustrating the method of handaxe analysis undertaken within this study.

Tip shapes were examined and classified according to McNabb et al. (2004), where the top third of the artefact is considered the tip and assigned to one of seven potential categories (Fig. 2A). By classifying biface tip shapes through such a schema, it should be possible to ascertain what tip shapes were being produced and allow comparison on an intra- and interassemblage basis. This in turn should determine whether there were any preferences (or not) for particular tip shapes within each assemblage. The extent of secondary flaking on both faces of the handaxe was classified according to Figure 2B. Such an assessment of the secondary flaking or biface shaping strategies should allow for an analysis of biface manufacture in regard to standardized methods of imposing form onto a blank. This, in turn, should illustrate whether hominins were making bifaces in a culturally determined method of manufacture-if the bifaces were all made using the same shaping strategy - or whether individual preference or ability played more of a governing factor in biface production - a more random pattern of shaping within the data (McNabb et al. 2004).

Given the broad behavioural scale of the analysis presented here, the methodology for investigating symmetry as laid out by McNabb et al. (2004) (Fig. 2C) is appropriate for this task. Although there have been valid criticisms of this methodology (Machin \& Mithen 2004; Underhill 2007), they have mostly focused upon the subjectivity of the system of analysis in regard to the fine-grained data scrutiny required for studying biface symmetry within tightly constrained time periods and the desire for a metric quantification of symmetry (e.g. Hardaker \& Dunn 2005; Iovita \& McPherron 2011; Marshall et al. 2002). However, in response, McNabb raises a cogent point when stating that if symmetry was important to the original knappers, appreciation by eye would have been the method through which they judged the results of their handiwork. A simple eyeball test of symmetry does therefore reflect this process' (McNabb 2009, 87). Furthermore, it has long been acknowledged that humans recognize bilateral symmetry through visual inputs (Kootstra et al. 2011; Treder 2010) and therefore a byeye assessment such as the one followed here is suitable for the scale of inquiry being undertaken. Symmetry within this methodology is determined by dividing the artefact into three equal sections along the long axis on both faces (Fig. 2C). Each horizontal third of the artefact is then 'folded over' to determine whether the edge outlines are symmetrical around the line of the long axis and a simple 'yes' or 'no' score recorded. The artefact is then categorized by the three scores (for the tip, medial and base) and assigned to a symmetry category based on the eight possible combinations of scores. A further three symmetry categories were identified by McNabb et al. $(2004,658)$ : balanced, where an artefact may not be perfectly symmetrical, yet is still clearly balanced along the longitudinal axis; parallel distinctive features along the margin, where there are visually distinct features located in parallel along opposite edges of the artefact, such as notches or trimmed concavities; and profoundly asymmetrical tips, which are the clear result of working but appear bent or 'curved'. By assessing the imposition of symmetry upon bifaces using such a methodology, it is possible to compare the degree of standardization, as evidenced through the presence of symmetry, in biface morphology, both within and between assemblages. Such a comparison allows for an analysis of changing patterns of symmetry imposition against time in order to test the long-held assumption that the presence of symmetry within biface manufacture increases as 
time progresses (Hodgson 2015; Saragusti et al. 1998), and therefore that bifaces became increasingly important in mediating hominin social behaviour (e.g. Kohn \& Mithen 1999).

Continuing to follow McNabb et al. (2004) the amount of edge working was classified and recorded. The amount of edge working refers to the quantification of the amount of the edge that has been worked to finish the tool, with it being divided into 12 sections (6 on each face). Each section of the artefact was scored according to the specifics laid out in Figure 2D, moving in an anti-clockwise direction from $\mathrm{T} 1$ to $\mathrm{T} 2$ and $\mathrm{T} 3$ to $\mathrm{T} 4$. Using this method for analysing the extent of edge working, a relative index is created with the minimum total score for an artefact regarding edge working being 12 and the maximum 60. For ease of analysis, groupings were made within the data set based on the total edge working score for each artefact. These groups constitute a broad index for edge working following the categories of: 12-24 (low index of edge working); 25-36 (medium to low index of edge working); 37-48 (medium to high index of edge working) and 49-60 (high index of edge working). By assessing the extent of edge working in this manner, it should be possible to analyse the degree to which hominin knappers are altering the shape and imposing form onto the biface through edge working. This in turn would also allow an assessment of whether there was a link between edge working and standardization in biface form, or whether biface form was governed predominantly by the secondary flaking strategy described above.

\section{Results}

Tip shape

Table 2 shows that from all the analysed assemblages, the most common form of biface tip contained a convergent element as opposed to a wide, divergent or convex shape. However, within the convergent tip shapes there would appear to be a diverse range of morphologies, with the most common tending to be convergent with a generalized tip or markedly convergent (Table 2). Convergent with a generalized tip tends to refer to those tip shapes that had a convergent element, but did not have a specific tip shape as described through markedly convergent, convergent with a square tip or convergent with an oblique tip. The implication for this in regards to standardized tip manufacture is that convergent with a generalized tip would imply that there was no regularity in regards to tip morphology apart from a generic convergence in overall form. Hoxne displays a clear preference for markedly convergent tip shape (54.2 per cent); however, the remaining 45.8 per cent of tips are spread across a wide range of morphologies. Similarly, the Et Tabun layers would seem to display a broad preference for markedly convergent tips (c. 30-38 per cent); however, as with Hoxne, the remaining tip shapes are spread through a variety of morphologies. Given the broad chronological arrangement of Table 2, it can further be seen that there would not appear to be a positive correlation between preferences for particular tip shapes in respect to time (on the basis that percentage of an assemblage reflects frequency of occurrence). Therefore, given the diverse range of tip shapes present within the data, it would appear that there was not one particular tip shape consistently sought after amongst the assemblages analysed.

\section{$<$ TABLE 2 NEAR HERE>}

\section{Extent and pattern of flaking}

The data for the extent and patterning of flaking are show in Table 3, where a number of patterns within the data can be seen. 
The Cave of Hearths suggests that the hominins seemed to have preferred a partial marginal method of thinning and shaping for both faces (first face $=84.3$ per cent, second face $=$ 81.6 per cent). This is the least work approach to thinning and shaping and implies that the hominins were not concerned about a standardized method of knapping in biface manufacture. From the small sample of bifaces at High Lodge, there would appear to be no consistent pattern in regards to biface shaping and thinning, although the preferred shaping strategy for both faces would appear to have been complete (first face $=53.3$ per cent, second face $=46.7$ per cent). The data from Warren Hill would suggest that the bifaces were shaped and thinned in a similar fashion on both faces, with a clear preference for bifaces that were completely worked (first face $=46.4$ per cent, second face $=46.0$ per cent), which may suggest a potential standardization in biface shaping. From Elveden, it can be seen that the hominins seem to have preferred a complete flaking secondary working strategy overall (first face $=47.7$ per cent, second face $=47.7$ per cent). From the small sample from the Hoxne Upper Industry, there would appear to be no consistent pattern in regards to biface shaping and thinning.

Et Tabun layer F shows that the hominins seem to have favoured the easiest shaping option, of a partial marginal flaking strategy overall (first face $=31.3$ per cent, second face $=$ 34.9 per cent). However, complete (first face $=21.7$ per cent, second face $=22.9$ per cent) and substantial (first face $=25.3$ per cent, second face $=20.5$ per cent) flaking extents, when combined, indicate a more intensive flaking strategy may have prevailed. Furthermore, the data suggests that the first and second faces were worked in broadly similar fashions, and if combined with the complete and substantial initial working, it is possible that the hominins of Layer F were imposing deliberate form through a standardized system of biface shaping or secondary working. Et Tabun layers Ea-Ed suggest that a partial marginal flaking strategy was favoured overall (first face $=34.0$ per cent, second face $=38.1$ per cent). Furthermore, the data suggest that the first and second faces may have been worked in broadly similar fashions, which, in turn, may indicate a standardized system of biface shaping. The data from Broom Pits show that a complete thinning and shaping strategy (first face $=43.6$ per cent, second face $=$ 41.8 per cent) was preferred at the site. Furthermore, the data suggest that the first and second faces were worked in a broadly similar fashion. From Et Tabun layer D, it would seem that a partial marginal flaking strategy (the easiest flaking option) was favoured (first face $=66.7$ per cent, second face $=50.0$ per cent). However, complete, complete marginal and substantial flaking extents are also represented within the sample. Furthermore, the data suggests that the first and second faces were worked in different fashions, suggesting a lack of standardization in biface production or at least a reflection of local social practice of working the first and second faces differently; although, admittedly, the limited sample size for Et Tabun layer D does makes it difficult to ascertain whether this is a genuine reflection of hominin behaviour.

From the small sample of bifaces from Pontnewydd Cave assemblage, there would appear to be a preference for partial marginal preparation (first face $=63.8$ per cent, second face $=56.9$ per cent) in regard to biface shaping and thinning. It should be noted here that this type of shaping and thinning requires the least amount of work and does not contribute hugely to form imposition. From Cuxton, it would appear that there was not a preferred secondary flaking strategy in place, although partial marginal flaking would seem to hold a small majority (first face $=22.6$ per cent, second face $=33.3$ per cent). Interestingly, the two sides of the bifaces often seem to be knapped in different ways overall, with the first face having more bifaces that were worked in a complete fashion (24.2 per cent) than the second face (12.4 per cent), and fewer bifaces that were worked in a partial fashion (first face $=14.5$ per cent, second face $=17.7$ per cent). Therefore, it would seem that the patterns of secondary working support the idea that there are no clear patterns of standardization in shaping and thinning within the bifaces from Cuxton. The data for the site of Lynford show that there appears to have been a favoured 
complete (first face $=51.0$ per cent, second face $=47.1$ per cent) and substantial (first face $=31.4$ per cent, second face $=33.3$ per cent) secondary flaking strategy. Furthermore, the data suggest that the first and second faces were worked in a broadly similar and intensive fashion, which may indicate that the hominins of Lynford Quarry were working bifaces through a standardized system of secondary flaking and shaping.

\section{Symmetry}

Table 4 shows that the presence of symmetry within biface form does not appear to be a significant component of the assemblages analysed here, regardless of temporal or geographical range.

\section{<TABLE 4 NEAR HERE>}

Fully non-symmetrical bifaces (no,no,no) from each assemblage are the largest category from each assemblage by some considerable degree. In contrast, pure symmetry (yes,yes,yes) remains a consistently minor component (less than 8 per cent) of any assemblage at any time. Fully symmetrical bifaces were clearly capable of being produced (and indeed they were at all sites); however, the frequency of occurrence within each assemblage through time may indicate that the imposition of perfect or true symmetry on biface form was not a defining factor in most instances of biface manufacture. In regard to near symmetry within biface form (categories that have at least one 'yes'), Table 4 shows that, when compared to the non-symmetrical category, the percentage of bifaces that have some degree of symmetry present on their form do not cluster in any particular category, but are spread across the dataset. This may add some additional weight to the notion that the presence of symmetry was not a crucial factor in the majority of biface manufacture. In addition, given that the sites in Table 4 are arranged in a broad chronological order, it becomes clear that the presence of pure symmetry does not increase to any large degree through time (on the basis that percentage of an assemblage reflects frequency of occurrence). Indeed, both within and between assemblages, there would appear to be no consistent pattern to symmetry presence from any assemblage across the entire data set.

\section{Extent of edge working}

The edge working analysis gives an overall quantification of edge working for the entire biface. Using this method, a relative index of edge working is created, with the minimum total score for an artefact regarding edge working being 12 and the maximum total score 60 . For ease of analysis, groupings were made within the data set based on the total edge working score for each artefact, the results of which may be seen in Table 5 .

\section{<TABLE 5 NEAR HERE>}

From Table 5, it can be seen that the majority of bifaces have a varied degree of edge working from all assemblages. However, there may be two broad patterns that are evident within Table 5: firstly, the sites that fall within the realm of the Lower Palaeolithic (Cave of Hearths, High Lodge, Warren Hill, Elveden, Hoxne Upper Industry, Et Tabun F and Ea-Ed, and Broom Pits) seem to display an edge working strategy that is more intensive, in that there would appear to be a greater degree of edge working - instances with a medium-to-high or high index when contrasted to those sites of the Middle Palaeolithic (Et Tabun D, Pontnewydd Cave, Cuxton and Lynford). In spite of this, within these two broad groupings (Lower and Middle Palaeolithic) there would not appear to be any indication of a standardized edge working strategy between the sites, as would be expected if edge working was utilized in 
creating deliberate form on the bifaces. Rather, each assemblage's edge working strategy appears mixed in distribution between a low to high index and therefore may reflect a response to functional rather than social requirements.

Table 6 below shows the relationship between site, edge working index and symmetry. The premise being explored here is that a high degree of edge working should correlate positively to a high degree of symmetry, if edge working were crucial to the imposition of symmetry upon biface form.

\section{<TABLE 6 NEAR HERE>}

Table 6 shows that there does not appear to be a strong relationship between degree of edge working and the presence of symmetry in regards to any assemblage. Indeed, where symmetry is present on a biface, Table 6 shows that the degree of edge working falls within the medium-to-low and low indices as often as they are in the medium-to-high and high indices. Furthermore, the presence of edge working and symmetry appears to be distributed in a mixed fashion throughout the assemblages, with no increase in correlation through time. This in turn may suggest that edge working could represent a response to functional requirements, rather than specific form imposition in the guise of symmetry.

Table 7 shows the relationship between site, edge working index and tip shape. The premise being explored here is to see whether there is a correlation between edge working (over the whole biface) and specific tip shapes. This is done in order to establish whether particular biface tip shape morphology (convergent versus non-convergent) can be positively correlated to degrees of edge working, in that if particular biface forms are shaped through secondary edge working, then the degree of edge working should be grouped in the mediumto-high or high index groups for particular tip shapes.

\section{<TABLE 7 NEAR HERE>}

Table 7 shows that there does not appear to be a strong relationship between degree of edge working and tip shape through time on the basis of percentages reflecting frequency of occurrence. Indeed, the indices of edge working for all assemblages and tip shapes are predominantly held within the medium to low and low indices for edge working. This would imply that edge working was not utilized as a means of modifying tip shape to any great extent. This in turn suggests that secondary biface working or shaping was sufficient to achieve the desired biface form (in terms of tip shape and symmetry) and may support the notion that biface edge working was restricted to adapting the biface on a functional level. Alternatively, the lack of edge working seen in relation to tip shape and symmetry may suggest that secondary working of the biface was not required on any extensive scale to maintain or create the form of biface required by the knapper. Either way, the results from Tables 6 and 7 would suggest an overall lack of a standardized approach to biface manufacture and form imposition through tip shape or symmetry through time. Although it should be noted that there is clearly deliberate imposition of shape and form present within the knapping of the bifaces studied, it just does not seem to reflect the patterns of standardization and increasing symmetrical presence expected from the wider literature (Ambrose 2001; Hodgson 2015; Saragusti et al. 1998)

\section{Discussion and conclusion}

It is now possible to return to the research questions posed at the beginning of this paper (Acheulean handaxes are often made to a symmetrical mental template; symmetrical handaxes 
are present in large quantities throughout Acheulean assemblages; and the presence of symmetrical handaxes within Acheulean assemblages increases through time as a marker of increasing hominin cognitive ability) and summarize the results described above.

The investigations regarding standardization of form imposition through symmetry and particular tip shape show that absolute biface symmetry has very little presence (less than 8 per cent) in all assemblages included within this study across time and space. The majority of the bifaces from all the assemblages under interrogation were in fact found to be completely nonsymmetrical in form, reiterating that absolute symmetry seems to have played a limited role in biface production within the Lower and Middle Palaeolithic. The most common tip shape from all assemblages had a convergent element to them. When tips with a symmetrical component to their form were compared to tips that were convergent, it was found that there was a direct correlation between convergence in tip shape and presence of symmetry. This may imply that the symmetry present within the assemblages might have been as much a result of the extra working and shaping relating to producing a convergent tip as a deliberate and intended outcome of the knapper. It is unclear at this stage whether convergent tips were seen as culturally significant biface forms, although, given the wide range of convergent tip types and the overall lack of secondary working or shaping and edge working associated with convergent tips, it seems likely that tip convergence may have been a functionally driven form rather than a desired end-product made to a specific cultural norm. Therefore, from all the sites ranging from the Lower to Middle Palaeolithic under examination within this sample, there would appear to be an overall lack of a standardized imposition of biface form, including symmetry and tip shape.

Investigations into the secondary working or biface shaping strategies showed that there were four sites (High Lodge, Hoxne Upper Industry, Et Tabun layer D and Cuxton) that did not display any evidence for a standardized approach to secondary working or shaping for the first and second faces of the bifaces under examination. The remaining eight sites (Cave of Hearths, Warren Hill, Elveden, Et Tabun layers F and Ea-Ed, Broom Pits, Pontnewydd Cave and Lynford) did display similar working strategies for the first and second biface faces. This may indicate a standardization in biface production, possibly reflecting a learnt behaviour on how to produce a biface rather than a culturally mediated knapping strategy, although such a conclusion should be subject to further testing.

In terms of edge working, it has been shown that the edge working index across all the sites was predominantly in the medium-to-low and low categories, which would seem to imply that edge working, when present on bifaces, did not play a major component in biface form imposition and may subsequently be limited to functional requirements. Furthermore, the lack of association between edge working and the clear links to the imposition of symmetry or particular tip form may add further support to the notion that secondary edge working was not used to refine the aesthetics of the handaxe.

By arranging the sites in all tables in a broadly chronological fashion, it has been possible to assess whether patterns relating to symmetry imposition, tip shape, secondary working or shaping and edge working change in relation to time. The results would seem to indicate that there is no obvious chronological progression present within this data set. That is to say, there is no indication of any of the criteria discussed above increasing or decreasing in frequency in a progressive manner through time. Rather, the data distributions seem to be rather mixed in their patterns, which may be an indication of local adaptations to specific functional requirements for each site at each individual occupation event.

Whilst symmetry may have been deliberately imposed on a small minority of artefacts, contrary to popular belief (e.g. Ambrose 2001; Hodgson 2015) symmetry does not seem to play a major role in overall biface manufacture, regardless of temporal or geographic range within the data sets studied here. In addition, there would appear to be a great variety in handaxe 
form with a clear lack of a standardized imposition of tip shape, biface shaping and edge working within the bifaces studied. Therefore, current frameworks of interpretation which see the need for a majority expression of symmetry and standardization within assemblages for artefacts to be significant within systems of social communication may need revising. Indeed, the data presented here rather suggest that, if the Acheulean hominins used handaxes as social proxies, it may not have been expressed through the predominance of biface symmetry or standardization within an assemblage, but it is perhaps the expression of symmetry and standardization in small numbers that is significant, where only selected or individual artefacts were knapped with a symmetrical template in mind and used to negotiate the inter and intragroup socialscapes of the knappers.

Furthermore, from the data presented within this paper, it is clear that, although Acheulean hominins do pay attention to imposing form on to handaxes, it is just not a single preferred or standardized form repeated throughout an assemblage. Indeed, from the range of tip shapes presented within this data set (if it is accepted that tip shape can be a broad proxy for biface form), it would seem that there is a great deal of variation in biface form within any given assemblage. Perhaps it is the variation of final biface form that is significant in understanding and interpreting past hominin behaviour. The variety of form within and between the assemblages examined would seem to indicate that the hominins responsible may have had a sense of 'conceptual standardization', where the notion of the handaxe was socially generated and sustained within a group; however, the final form for the majority of the handaxes was not determined through strong social imposition or social learning (McNabb et al. 2004), but perhaps linked to raw material quality, knapping skill and functional requirement.

One possibility may be that the lack of full standardization or symmetry in handaxe manufacture may indicate that the hominin knappers imitating their contemporaries did not quite realize what it was that their contemporaries were imagining in relation to final handaxe form. By this it is suggested that perhaps individuals recognized a handaxe was being made but could not access the exact imagined shape of the handaxe in their contemporaries' mind and therefore could not emulate or standardize the shape of handaxes across the group. If individuals could not access each other's imaginations, then it stands to reason that they may therefore have been unable to realize the full potential of consciously off-loading social communications and culturally meaningful symbols on to the material culture with which they interacted. This, in turn, has possible implications regarding the ability for a Theory of Mind and language as discussed elsewhere (Cole 2012; 2014a,b; 2015).

An alternative possibility is that perhaps the application of notions of symmetry and standardization used as proxies for cultural agreement or symbolism, as is often inferred by modern researchers to artefacts made by non-modern human species, may be an inappropriate way in which to examine the Palaeolithic record. Perhaps researchers should re-address the degree to which we associate standardization with agreed cultural practice, or at least develop clear definitions regarding standardization and implied behavioural implications, rather than trying to pigeon-hole hominin behaviour in a way that is not apparent in, or necessarily appropriate for, the archaeological record.

From the data presented here, it would appear that the use of bifaces deliberately to mediate social relationships by archaic hominins may not have been expressed through the regular or constant imposition of symmetry or a specifically favoured form, although there is clear evidence that bifaces are deliberately shaped and symmetry is present in small proportions within each assemblage studied. What this paper seeks to highlight in part is the need to test the behavioural interpretations of hominins against large, assemblage-wide datasets, rather than small and potentially biased samples. Clearly, therefore, more work needs to be done to test the observations presented here against different assessments of symmetry 
and form imposition on handaxes and this should be done on a dataset that is at least comparable to the size presented here - and if possible larger.

In addition, there are some intriguing possibilities within the Acheulean record that may suggest that hominins occasionally made the cognitive leap to engage with material culture beyond function. For example, the presence of extraordinary artefacts such as giant handaxes within a small sample of Acheulean assemblages (e.g. Kelley 1965; Wenban-Smith 2004) throws up the intriguing prospect of the ways in which individual artefacts within assemblages may carry more social weight than their counterparts, although it should be noted that the exact function of giant handaxes and their role within wider Acheulean assemblages is still unclear and in need of further work (Wenban-Smith \& Cole in prep.). Similarly, the question of specific variants such as the twisted ovates known from MIS 11 (White 1998b) or the handaxe pairs from Boxgrove and Foxhall Road (Hopkinson \& White 2005; Pope et al. 2006; White \& Plunkett 2004) also offer up interesting implications for handaxe use in social signals. Seen through the filter of this paper, what emerges is the picture of hominins that are capable of producing extraordinary artefacts (including symmetrical pieces) on a localized independent scale that perhaps represent innovations where a specific cognitive link with material culture and its potential symbolic role has been made within mediating social relationships (Cole 2015). However, for some reason presumably linked to limited social networks between distinct hominin groups, the notion that material culture can play an active and constant role in mediating complex social relationships at this point in time is not taken up at the broader species level of behaviour.

\section{Acknowledgements}

This paper was based on my Ph.D thesis supported by a full grant as part of the British Academy Centenary Project 'From Lucy to language: the archaeology of the social brain' and I will be eternally grateful for the time, intellectual consideration and financial support graciously given by the project and its three directors, Clive Gamble, Robin Dunbar and John Gowlett. I would also like to thank John McNabb, Rob Hosfield and William Davies, whose unceasing guidance through my thesis proved more valuable that I can possibly say. Thanks must also extend to John McNabb for access to the Cave of Hearths photographic database and to the Cambridge Museum of Archaeology and Anthropology, the National Museum in Cardiff and Frank's House, The British Museum for access to the Tabun and British site assemblages. Furthermore, thanks to the two anonymous reviewers whose comments and suggestions were extremely valuable and helpful. Any errors that remain within this paper are entirely my own.

James Cole
School of Environment and Technology
University of Brighton
Cockcroft Building
Lewes Road
Brighton BN2 4GJ
UK
Email: J.N.Cole@brighton.ac.uk

\section{References}

Aldhouse-Green, S., 1998. The archaeology of distance: perspectives from the Welsh Palaeolithic, in Stone Age Archaeology: Essays in Honour of John Wymer, eds. N. Ashton, F. Healy \& P. Pettitt. (Lithic Studies Society Occasional Paper 6.) Oxford: Oxbow, 137-45. Ambrose, S.H., 2001. Paleolithic technology and human evolution. Science 291, 1748-53. 
Ashton, N., J. Cook, S.G. Lewis \& J. Rose (eds.), 1992. High Lodge: Excavations by G. de G. Sieveking 1962-8, and J. Cook, 1988. London: British Museum Press.

Ashton, N., S.G. Lewis, S.A. Parfitt, et al., 2005. Excavations at the Lower Palaeolithic site at Elveden, Suffolk, UK. Proceedings of the Prehistoric Society 71,1-61.

Ashton, N., S.G. Lewis, S.A. Parfitt, K.E.H. Penkman \& G.R. Coope, 2008. New evidence for complex climate change in MIS-11 from Hoxne, Suffolk, UK. Quaternary Science Reviews 27(7-8), 652-68.

Ashton, N. \& J. McNabb, 1994. Bifaces in perspective, in Stories in Stone, eds. N. Ashton \& A. David. (Lithic Studies Society Occasional Paper 4.) London, 182-191

Boismier, W.A., C.S. Gamble \& F. Coward (eds.), 2012. Neanderthals among Mammoths: Excavations at Lynford Quarry, Norfolk. Swindon: English Heritage.

Chase, P.G., 1991. Symbols and Paleolithic artifacts: style, standardization, and the imposition of arbitrary form. Journal of Anthropological Archaeology 10, 193-214.

Cole, J., 2011. Hominin Cognitive and Behavioural Complexity in the Pleistocene: Assessment through Identity, Intentionality and Visual Display. PhD dissertation, University of Southampton. http:/ / eprints.soton.ac.uk/209627/

Cole, J., 2012. The Identity Model: a method to access visual display within the Palaeolithic. Human Origins 1, 24-40.

Cole, J., 2014a. Hominin language development: a new method of archaeological assessment. Biosemiotics 8 (1): 67-90.

Cole, J., 2014b. The Identity Model: a theory to access visual display and hominin cognition within the Palaeolithic, in Lucy to Language: Benchmark Papers, eds. R.I.M. Dunbar, C.S. Gamble \& J.A.J. Gowlett. Oxford: Oxford University Press, 90-107.

Cole, J., 2015. Handaxe symmetry in the Lower and Middle Palaeolithic: implications for the Acheulean gaze, in Settlement, Society and Cognition in Human Evolution: Landscapes in Mind, eds. F. Coward, R.T. Hosfield, M. Pope \& F. Wenban-Smith. Cambridge: Cambridge University Press, 234-257.

Frere, J., 1800. Account of flint weapons discovered at Hoxne in Suffolk. Archaeologia 13, 204-5. Gamble, C.S., 1996. Hominid behaviour in the Middle Pleistocene: an English perspective, in The English Palaeolithic Reviewed, eds. C.S. Gamble \& A.J. Lawson. Salisbury: Trust for Wessex Archaeology, 63-71.

Gamble, C.S., 1998. Handaxes and Palaeolithic individuals, in Stone Age Archaeology: Essays in honour of John Wymer, eds. N. Ashton, F. Healy \& P. Pettitt. (Lithic Studies Society Occasional Paper 6.) Oxford: Oxbow, 105-109.

Gamble, C.S. \& R. Kruszynski, 2009. John Evans, Joseph Prestwich and the stone that shattered the time barrier. Antiquity 83, 461-75.

Gowlett, J.A.J., 2011. Special Issue: Innovation and the Evolution of Human Behavior. The Vital Sense of Proportion: Transformation, Golden Section, and 1:2 Preference in Acheulean Bifaces. PaleoAnthropology 2011, 174-87.

Hardaker, T. \& S. Dunn, 2005. The flip test - a new statistical measure for quantifying symmetry in stone tools. Antiquity 79(306), http:/ / antiquity.ac.uk/ projgall/hardaker

Hodgson, D., 2009. Evolution of the visual cortex and the emergence of symmetry in the Acheulean techno-complex. Comptes Rendus Palevol 8, 93-7.

Hodgson, D., 2015. The symmetry of Acheulean handaxes and cognitive evolution. Journal of Archaeological Science: Reports 2, 204-8.

Hopkinson, T. \& M.J. White, 2005. The Acheulean and the handaxe: structure and agency in the Palaeolithic, in The Hominid Individual in Context: Archaeological investigations of Lower and Middle Palaeolithic landscapes, locales and artefacts, eds. C.S. Gamble \& M. Porr. London/New York: Routledge, 13-28. 
Hosfield, R.T., 2011. The British Lower Palaeolithic of the early Middle Pleistocene. Quaternary Science Reviews 30, 1486-510.

Hosfield, R.T. \& J.C. Chambers, 2009. Genuine diversity? The Broom biface assemblage. Proceedings of the Prehistoric Society 75, 65-100.

Iovita, R. \& S.P. McPherron, 2011. The handaxe reloaded: a morphometric reassessment of Acheulian and Middle Paleolithic handaxes. Journal of Human Evolution 61, 61-74.

Kelley, H., 1965. Bifaces de dimensions exceptionelles, in Congrès préhistorique de France: compte rendu de la XVIe session, Principauté de Monaco, 28 aout-5 septembre 1959. Paris: Société préhistorique française, 739-72.

Kohn, M. \& S. Mithen, 1999. Handaxes: products of sexual selection? Antiquity 73, 518-26.

Kootstra, G., B. de Boer \& L.R.B. Schomaker, 2011. Predicting eye fixations on complex visual stimuli using local symmetry. Cognitive Computation 3(1), 223-40.

Lepre, C.J., H. Roche, D.V. Kent, S. Harmand, R.L. Quinn, J.-P. Brugal, P.-J. Texier, A. Lenoble \& C.S. Feibel, 2011. An earlier origin for the Acheulian. Nature 477, 82-5.

Machin, A., 2009. The role of the individual agent in Acheulean biface variability: a multifactorial model. Journal of Social Archaeology 9(1), 35-58.

Machin, A., R.T. Hosfield \& S.J. Mithen, 2007. Why are some handaxes symmetrical? Testing the influence of handaxe morphology on butchery effectiveness. Journal of Archaeological Science 34, 883-93.

Machin, A. \& S. Mithen, 2004. Reply to McNabb et al. (2004). The large cutting tools from the South African Acheulean and the questions of social traditions. Current Anthropology 45(5), 653-77.

Marshall, G.D., D. Dupplaw, D.A. Roe \& C.S. Gamble, 2002. Lower Palaeolithic technology, raw material and population ecology. York: Archaeology Data Service.

McNabb, J., 2007. The British Lower Palaeolithic: Stones in Contention. London/New York (NY): Routledge.

McNabb, J., 2009. The ESA stone tool assemblage from the Cave of Hearths, Beds 1-3, in The Cave of Hearths: Makapan Middle Pleistocene Research Project: Field Research by Anthony Sinclair and Patrick Quinney, 1996-2001, eds. J. McNabb \& A. Sinclair. Oxford: Archaeopress, 75-104.

McNabb, J., 2013. Pole to pole. Archaeology and adaptation in the Middle Pleistocene at opposite ends of the Acheulean world. Oxford Journal of Archaeology 32(2), 123-46.

McNabb, J., F. Binyon \& L. Hazelwood, 2004. The large cutting tools from the South African Acheulean and the questions of social traditions. Current Anthropology 45(5), 653-77.

McNabb, J. and Sinclair, A. (Eds). 2009. The Cave of Hearths: Makapan Middle Pleistocene Research Project: Field research by Anthony Sinclair and Patrick Quinney, 1996-2001. University of Southampton Series In Archaeology No 1. Oxford, Archaeopress.

McPherron, S.P., 1999. Ovate and pointed handaxe assemblages: two points make a line. Préhistoire Européenne 14, 9-32.

McPherron, S.P., 2000. Handaxes as a measure of the mental capabilities of early hominids. Journal of Archaeological Science 27, 655-63.

McPherron, S.P., 2009. Perspectives on stone tools and cognition in the early Palaeolithic record, in Tool Use in Animals: Cognition and Ecology, eds. C. Sanz, J. Call \& C. Boesch. New York (NY): Cambridge University Press, 286-309.

Mellars, P., 1989. Major issues in the emergence of modern humans. Current Anthropology 30, 349-85.

Mellars, P., 1991. Cognitive changes and the emergence of modern humans in Europe. Cambridge Archaeological Journal 1, 63-76. 
Mercier, N., H. Valladas, G. Valladas, J.-L. Reyss, A.J. Jelinek, L. Meignen \& J.-L. Joron, 1995. TL dates of burnt flints from Jelinek's excavations at Tabun and their implications. Journal of Archaeological Science 22, 495-509.

Monnier, G.F., 2006. Testing retouched flake tool standardisation during the Middle Palaeolithic: patterns and implications, in Transitions Before the Transition: Evolution and stability in the Middle Palaeolithic and the Middle Stone Age, eds. E. Hovers \& S.L. Kuhn. New York: Springer, 57-84.

Pope, M., K. Russel \& K. Watson, 2006. Biface form and structured behaviour in the Acheulean. Lithics 27, 44-57.

Porr, M., 2005. The making of the biface and the making of the individual, in The Hominid Individual in Context: Archaeological investigations of Lower and Middle Palaeolithic landscapes, locales and artefacts, eds. C.S. Gamble \& M. Porr. London/New York (NY): Routledge, 68-80.

Rink, W.J., H.P. Schwarcz, A. Ronen \& A. Tsatskin, 2004. Confirmation of a near $400 \mathrm{ka}$ age from the Yabrudian industry at Tabun Cave, Israel. Journal of Archaeological Science 31, 15-20.

Ronen, A. (ed.), 1982. The Transition from the Lower to Middle Palaeolithic and the Origins of Modern Man. (BAR International Series S151.) Oxford: British Archaeological Reports.

Saragusti, I., A. Karasik, I. Sharon \& U. Smilansky, 2005. Quantitative analysis of shape attributes based on contours and section profiles in archaeological research. Journal of Archaeological Science 32, 841-53.

Saragusti, I., I. Sharon, O. Katzenelson \& D. Avnir, 1998. Quantitative analysis of the symmetry of artefacts: Lower Paleolithic handaxes. Journal of Archaeological Science 25, 817-25.

Spikins, P., 2012. Goodwill hunting? Debates over the 'meaning' of Lower Palaeolithic handaxe form revisited. World Archaeology 44(3), 378-92.

Stout, D. \& T. Chaminade, 2009. Making tools and making sense: complex, intentional behaviour in human evolution. Cambridge Archaeological Journal 19(1), 85-96.

Thieme, H., 1997. Lower Palaeolithic hunting spears from Germany. Nature 385, 807-10.

Thieme, H., 2005. The Lower Palaeolithic art of hunting: the case of Schöningen 13 II-4, Lower Saxony, Germany, in The Hominid Individual in Context: Archaeological investigations of Lower and Middle Palaeolithic landscapes, locales and artefacts, eds. C.S. Gamble \& M. Porr. London/New York (NY): Routledge, 115-32.

Toth, N., 1990. The prehistoric roots of a human concept of symmetry. Symmetry: Culture $\mathcal{E}$ Science, 1(3), 257-81.

Treder, M.S., 2010. Behind the looking-glass: a review on human symmetry perception. Symmetry 2, 1510-43.

Underhill, D., 2007. Subjectivity inherent in by-eye symmetry judgements and the large cutting tools at the Cave of Hearths, Limpopo Province, South Africa. Papers from the Institute of Archaeology 18, 1-12.

Warren, S.H., 1911. On a Palaeolithic (?) wooden spear. Quarterly Journal of the Geological Society of London 67, xcix.

Wenban-Smith, F., 2004. Handaxe typology and Lower Palaeolithic cultural development: ficrons, cleavers and two giant handaxes from Cuxton. Lithics 25, 11-21.

Wenban-Smith, F.F., M.R. Bates \& G.D. Marshall, 2007. Medway Valley Palaeolithic Project Final Report: The Palaeolithic Resource in the Medway Gravels (Kent). Unpublished report submitted to English Heritage.

White, M.J., 1998a. On the significance of Acheulean biface variability in Southern Britain. Proceedings of the Prehistoric Society 64, 15-44.

White, M.J., 1998b. Twisted ovate bifaces in the British Lower Palaeolithic: some observations and implications, in Stone Age Archaeology: Essays in honour of John Wymer, eds. N. 
Ashton, F. Healy \& P. Pettitt. (Lithic Studies Society Occasional Paper 6.) Oxford: Oxbow, 98-104.

White, M.J., 2000. The Clactonian question: on the interpretation of core-and-flake assemblages in the British Lower Palaeolithic. Journal of World Prehistory 14, 1-63.

White, M.J. \& S.J. Plunkett, 2004. Miss Layard excavates: a Palaeolithic site at Foxhall Road, Ipswich, 1903-1905. Liverpool: Western Academic \& Specialist Press.

Wynn, T., 1995. Handaxe enigmas. World Archaeology 27, 10-23.

Wynn, T., 2004. Comments on McNabb et al. 2004, 'The large cutting tools from the South African Acheulean and the questions of social traditions'. Current Anthropology 45(5), 653-77.

\section{Author biography}

James Cole was born in Harare, Zimbabwe, and graduated from the University of Southampton in 2004 with a BA (Hons) first class distinction in Archaeology and again in 2006 with an MA in Human Origins (distinction), and a Ph.D in Archaeology funded by the British Academy Centenary Project 'Lucy to Language: the Archaeology of the Social Brain' in 2011. He has since lectured at the Universities of Southampton, Bournemouth, Royal Holloway and Oxford, before taking up a Lectureship at the University of Brighton. His main interests are in cognitive archaeology, the development of language and the hominins of the Lower to Middle Palaeolithic. 
Table 1. Assemblages used in this study. MIS = Marine Isotope Stage.

\begin{tabular}{lllll}
\hline Site & Location & N & Age/MIS & Reference \\
\hline Cave of Hearths & South Africa & 223 & $600-400 \mathrm{kya} / 15-11$ & McNabb \& Sinclair 2009 \\
High Lodge & UK & 15 & $500 \mathrm{kya} / 13$ & Ashton et al. $1992 ;$ Hosfield 2011 \\
Warren Hill & UK & 548 & $528-474 \mathrm{kya} / 13$ & Hosfield 2011 \\
Elveden & UK & 44 & $427-364 \mathrm{kya} / 11$ & Ashton et al. 2005 \\
Hoxne Upper Industry & UK & 24 & $427-364 \mathrm{kya} / 11$ & Ashton et al. 2008 \\
Et Tabun F & Israel & 83 & $>330 \mathrm{kya} / 10$ & Mercier et al. 1995; Rink et al. 2004 \\
Et Tabun Ea-Ed & Israel & 530 & $330-306 \mathrm{kya} / 9$ & (Mercier et al. 1995; Rink et al. 2004 \\
Broom Pits & UK & 912 & $334-301 \mathrm{kya} / 9$ & Hosfield \& Chambers 2009 \\
Et Tabun D & Israel & 6 & $270-263 \mathrm{kya} / 8$ & (Mercier et al. 1995; Rink et al. 2004 \\
Pontnewydd Cave & UK & 58 & $214-170 \mathrm{kya} / 7$ & Aldhouse-Green 1998; McNabb 2007 \\
Cuxton - Tester Collection & UK & 186 & $230-200 \mathrm{kya} / 7$ & (Wenban-Smith et al. 2007 \\
Lynford & UK & 51 & $65-57 \mathrm{kya} / 4-3$ & Boismier et al. 2012 \\
\hline
\end{tabular}


Table 2. Relationship between assemblage and tip shape. PA=profoundly asymmetrical.

\begin{tabular}{|c|c|c|c|c|c|c|c|c|c|}
\hline & \multicolumn{9}{|c|}{ Tip shape } \\
\hline & $\begin{array}{c}\text { Markedly } \\
\text { convergent } \\
\%\end{array}$ & $\begin{array}{c}\text { Convergent } \\
\text { with square } \\
\text { tip } \\
\%\end{array}$ & $\begin{array}{c}\text { Convergent } \\
\text { with } \\
\text { oblique tip } \\
\%\end{array}$ & $\begin{array}{c}\text { Convergent } \\
\text { with } \\
\text { generalized } \\
\text { tip } \\
\% \\
\end{array}$ & $\begin{array}{c}\text { Wide or } \\
\text { divergent } \\
\%\end{array}$ & $\begin{array}{c}\text { Wide or } \\
\text { divergent } \\
\text { with } \\
\text { oblique bit } \\
\%\end{array}$ & $\begin{array}{c}\text { Wide } \\
\text { with } \\
\text { convex } \\
\text { tip } \\
\% \\
\end{array}$ & $\begin{array}{c}\text { PA } \\
\%\end{array}$ & $\begin{array}{l}\text { Total } \\
\%\end{array}$ \\
\hline $\begin{array}{l}\text { Cave of Hearths } \\
N=223\end{array}$ & 10.3 & 13.0 & 4.5 & 22.9 & 29.6 & 13.9 & 5.8 & 0 & 100.0 \\
\hline $\begin{array}{l}\text { High Lodge } \\
N=15\end{array}$ & 20.0 & 0 & 6.7 & 60.0 & 6.7 & 6.7 & 0 & 0 & 100.0 \\
\hline $\begin{array}{l}\text { Warren Hill } \\
N=548\end{array}$ & 12.6 & 6.6 & 7.3 & 44.5 & 8.9 & 0 & 20.1 & 0 & 100.0 \\
\hline $\begin{array}{l}\text { Elveden } \\
N=44\end{array}$ & 18.2 & 4.5 & 4.5 & 63.6 & 0 & 0 & 4.5 & 4.5 & 100.0 \\
\hline $\begin{array}{l}\text { Hoxne Upper Industry } \\
N=24\end{array}$ & 54.2 & 12.5 & 8.3 & 4.2 & 8.3 & 0 & 12.5 & 0 & 100.0 \\
\hline $\begin{array}{l}\text { Et Tabun F } \\
N=83\end{array}$ & 38.6 & 8.4 & 4.8 & 18.1 & 7.2 & 0 & 22.9 & 0 & 100.0 \\
\hline $\begin{array}{l}\text { Et Tabun Ea-Ed } \\
N=530\end{array}$ & 30.8 & 10.6 & 5.5 & 26.6 & 5.1 & 0.2 & 20.6 & 0.8 & 100.0 \\
\hline $\begin{array}{l}\text { Broom Pits } \\
N=912\end{array}$ & 15.2 & 7.1 & 9.0 & 52.6 & 3.1 & 1.3 & 10.2 & 1.4 & 100.0 \\
\hline $\begin{array}{l}\text { Et Tabun D } \\
N=6\end{array}$ & 33.3 & 16.7 & 33.3 & 0 & 16.7 & 0 & 0 & 0 & 100.0 \\
\hline $\begin{array}{l}\text { Pontnewydd Cave } \\
N=58\end{array}$ & 12.1 & 8.6 & 3.4 & 63.8 & 6.9 & 0 & 3.4 & 1.7 & 100.0 \\
\hline $\begin{array}{l}\text { Cuxton } \\
N=186\end{array}$ & 17.2 & 4.3 & 4.8 & 58.1 & 2.7 & 1.6 & 9.1 & 2.2 & 100.0 \\
\hline $\begin{array}{l}\text { Lynford } \\
N=51\end{array}$ & 27.5 & 3.9 & 5.9 & 54.9 & 3.9 & 0 & 2.0 & 2.0 & 100.0 \\
\hline $\begin{array}{l}\text { Total } \\
N=2680\end{array}$ & 18.8 & 8.0 & 6.9 & 42.6 & 7.1 & 1.8 & 13.8 & 0.9 & 100.0 \\
\hline
\end{tabular}


Table 3. Relationship between assemblage and flaking extent.

\begin{tabular}{|c|c|c|c|c|c|c|c|c|c|c|c|c|c|}
\hline & Site & $\begin{array}{l}\text { Cave of } \\
\text { Hearths } \\
N=223\end{array}$ & $\begin{array}{l}\text { High } \\
\text { Lodge } \\
N=15\end{array}$ & $\begin{array}{l}\text { Warren } \\
\text { Hill } \\
N=548\end{array}$ & $\begin{array}{l}\text { Elveden } \\
N=44\end{array}$ & $\begin{array}{l}\text { Hoxne } \\
\text { Upper } \\
\text { Industry } \\
N=24\end{array}$ & $\begin{array}{l}\text { Et Tabun } \\
\text { F } \\
N=83\end{array}$ & $\begin{array}{l}\text { Et Tabun } \\
\text { Ea-Ed } \\
N=530\end{array}$ & $\begin{array}{l}\text { Broom } \\
\text { Pits } \\
N=912\end{array}$ & $\begin{array}{l}\text { Et Tabun } \\
\text { D } \\
N=6\end{array}$ & $\begin{array}{l}\text { Pontnewydd } \\
\text { Cave } \\
N=58\end{array}$ & $\begin{array}{l}\text { Cuxton } \\
N=186\end{array}$ & $\begin{array}{l}\text { Lynford } \\
N=51\end{array}$ \\
\hline \multirow{7}{*}{$\begin{array}{l}\text { Flaking } \\
\text { extent } \\
\text { first face }\end{array}$} & Complete $\%$ & 3.1 & 53.3 & 46.4 & 47.7 & 54.2 & 21.7 & 20.6 & 43.6 & 0 & 17.2 & 24.2 & 51.0 \\
\hline & $\begin{array}{l}\text { Complete } \\
\text { marginal \% }\end{array}$ & 9.0 & 0 & 8.6 & 2.3 & 4.2 & 9.6 & 7.2 & 7.3 & 0 & 5.2 & 2.2 & 0 \\
\hline & $\begin{array}{l}\text { Partial } \\
\text { marginal \% }\end{array}$ & 84.3 & 13.3 & 23.4 & 11.4 & 29.2 & 31.3 & 34.0 & 19.7 & 66.7 & 63.8 & 22.6 & 9.8 \\
\hline & Partial \% & 0.9 & 13.3 & 6.8 & 9.1 & 8.3 & 12.0 & 15.8 & 7.2 & 0 & 5.2 & 14.5 & 7.8 \\
\hline & Substantial \% & 2.2 & 20.0 & 15.0 & 29.5 & 4.2 & 25.3 & 22.5 & 22.0 & 33.3 & 8.6 & 36.6 & 31.4 \\
\hline & None $\%$ & 0.4 & 0 & 0 & 0 & 0 & 0 & 0 & 0 & 0 & 0 & 0 & 0 \\
\hline & Total \% & 100.0 & 100.0 & 100.0 & 100.0 & 100.0 & 100.0 & 100.0 & 100.0 & 100.0 & 100.0 & 100.0 & 100.0 \\
\hline \multirow{7}{*}{$\begin{array}{l}\text { Flaking } \\
\text { extent } \\
\text { second } \\
\text { face }\end{array}$} & Complete $\%$ & 1.3 & $\begin{array}{ll}46.7 \\
\end{array}$ & 46.0 & 47.7 & 8.3 & 22.9 & 13.4 & 41.8 & 33.3 & 13.8 & 12.4 & 47.1 \\
\hline & $\begin{array}{l}\text { Complete } \\
\text { marginal \% }\end{array}$ & 7.6 & 6.7 & 6.0 & 2.3 & 8.3 & 6.0 & 7.2 & 9.0 & 16.7 & 1.7 & 2.7 & 5.9 \\
\hline & $\begin{array}{l}\text { Partial } \\
\text { marginal \% }\end{array}$ & 81.6 & 26.7 & 24.5 & 15.9 & 25.0 & 34.9 & 38.1 & 15.8 & 50.0 & 56.9 & 33.3 & 11.8 \\
\hline & Partial \% & 0.4 & 13.3 & 7.8 & 13.6 & 16.7 & 14.5 & 21.3 & 7.2 & 0 & 13.8 & 17.7 & 2.0 \\
\hline & Substantial \% & 4.0 & 6.7 & 15.7 & 20.5 & 41.7 & 20.5 & 20.0 & 26.1 & 0 & 13.8 & 33.9 & 33.3 \\
\hline & None $\%$ & 4.9 & 0 & 0 & 0 & 0 & 1.2 & 0 & 0.1 & 0 & 0 & 0 & 0 \\
\hline & Total \% & 100.0 & 100.0 & 100.0 & 100.0 & 100.0 & 100.0 & 100.0 & 100.0 & 100.0 & 100.0 & 100.0 & 100.0 \\
\hline
\end{tabular}


Table 4. Relationship between assemblage and symmetry category. Pdf = Parallel distinctive features.

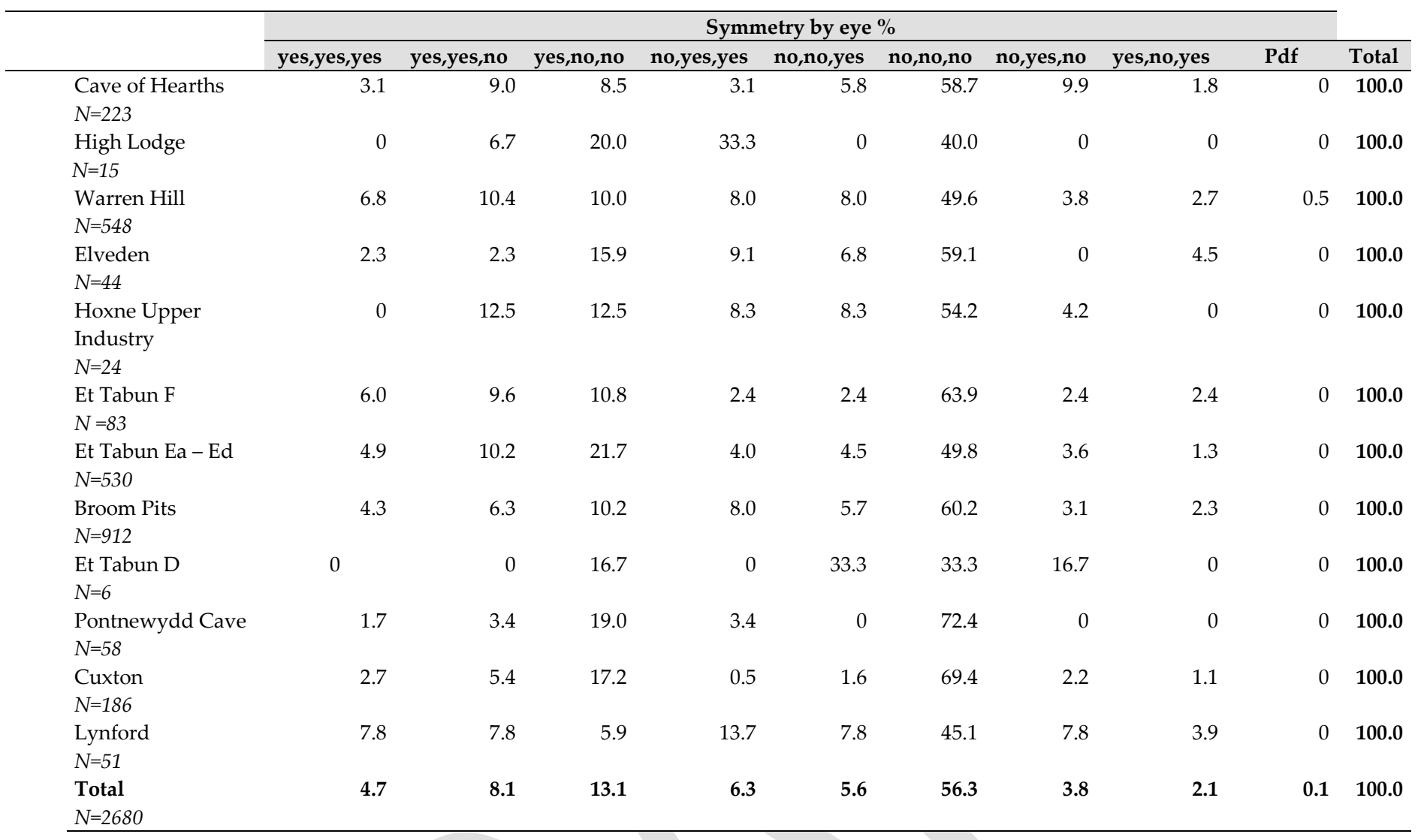


Table 5. Relationship between assemblage and extent of edge working.

\begin{tabular}{|c|c|c|c|c|c|}
\hline & \multicolumn{5}{|c|}{ Edge working (index) \% } \\
\hline & $\begin{array}{l}12-24 \\
\text { (low) }\end{array}$ & $\begin{array}{c}25-36 \\
\text { (medium-to-low) }\end{array}$ & $\begin{array}{c}37-48 \\
\text { (medium-to-high) }\end{array}$ & $\begin{array}{l}49-60 \\
\text { (high) }\end{array}$ & Total \\
\hline Cave of Hearths $N=223$ & 5.8 & 32.3 & 40.4 & 21.5 & 100.0 \\
\hline High Lodge $N=15$ & 0 & 53.3 & 46.7 & 0 & 100.0 \\
\hline Warren Hill $N=548$ & 21.0 & 64.1 & 14.6 & 4 & 100.0 \\
\hline Elveden $N=44$ & 34.1 & 59.1 & 6.8 & 0 & 100.0 \\
\hline Hoxne Upper Industry $N=24$ & 4.2 & 25.0 & 41.7 & 29.2 & 100.0 \\
\hline Et Tabun F N=83 & 39.8 & 28.9 & 14.5 & 16.9 & 100.0 \\
\hline Et Tabun Ea-Ed N=530 & 19.8 & 33.2 & 25.7 & 21.3 & 100.0 \\
\hline Broom Pits $N=912$ & 20.9 & 59.5 & 17.8 & 1.8 & 100.0 \\
\hline Et Tabun D N=6 & 33.3 & 16.7 & 16.7 & 33.3 & 100.0 \\
\hline Pontnewydd Cave $N=58$ & 69.0 & 29.3 & 1.7 & 0 & 100.0 \\
\hline Cuxton $N=186$ & 60.2 & 32.8 & 7.0 & 0 & 100.0 \\
\hline Lynford $N=51$ & 49.0 & 43.1 & 7.8 & 0 & 100.0 \\
\hline
\end{tabular}


Table 6. Relationship between assemblage, edge working index and symmetry by eye. Pdf=Parallel distinctive features.

\begin{tabular}{|c|c|c|c|c|c|c|c|c|c|c|c|}
\hline & & \multicolumn{10}{|c|}{ Symmetry by eye \% } \\
\hline & & yes,yes,yes & yes,yes,no & yes,no,no & no,yes,yes & no,no,yes & no,no,no & no,yes,no & yes,no,yes & Pdf & Total \\
\hline Cave of Hearths & 12-24 (low) & 0 & 0 & 0 & 0 & 0 & 4.9 & 0.9 & 0 & 0 & 5.8 \\
\hline \multirow{4}{*}{$N=223$} & 25-36 (medium-to-low) & 0 & 2.2 & 2.7 & 1.3 & 1.3 & 20.2 & 4.5 & 0 & 0 & 32.3 \\
\hline & 37-48 (medium-to-high) & 1.3 & 1.8 & 3.1 & 0.9 & 3.6 & 25.1 & 3.6 & 0.9 & 0 & 40.4 \\
\hline & 49-60 (high) & 1.8 & 4.9 & 2.7 & 0.9 & 0.9 & 8.5 & 0.9 & 0.9 & 0 & 21.5 \\
\hline & Total & 3.1 & 9.0 & 8.5 & 3.1 & 5.8 & 58.7 & 9.9 & 1.8 & 0 & 100.0 \\
\hline High Lodge & 12-24 (low) & 0 & 0 & 0 & 0 & 0 & 0 & 0 & 0 & 0 & 0 \\
\hline \multirow[t]{4}{*}{$N=15$} & 25-36 (medium-to-low) & 0 & 0 & 0 & 20.0 & 0 & 33.3 & 0 & 0 & 0 & 53.3 \\
\hline & 37-48 (medium-to-high) & 0 & 6.7 & 20.0 & 13.3 & 0 & 6.7 & 0 & 0 & 0 & 46.7 \\
\hline & $49-60$ (high) & 0 & 0 & 0 & 0 & 0 & 0 & 0 & 0 & 0 & 0 \\
\hline & Total & 0 & 6.7 & 20.0 & 33.3 & 0 & 40.0 & 0 & 0 & 0 & 100.0 \\
\hline Warren Hill & 12-24 (low) & 0.4 & 1.1 & 2.2 & 0.7 & 0.7 & 15.1 & 0.7 & 0 & 0 & 21.0 \\
\hline \multirow[t]{4}{*}{$N=548$} & 25-36 (medium-to-low) & 4.0 & 6.8 & 6.4 & 5.5 & 6.2 & 30.8 & 2.7 & 1.5 & 0.2 & 64.1 \\
\hline & 37-48 (medium-to-high) & 2.0 & 2.6 & 1.5 & 1.8 & 1.1 & 3.6 & 0.4 & 1.3 & 0.4 & 14.6 \\
\hline & 49-60 (high) & 0.4 & 0 & 0 & 0 & 0 & 0 & 0 & 0 & 0 & 0.4 \\
\hline & Total & 6.8 & 10.4 & 10.0 & 8.0 & 8.0 & 49.6 & 3.8 & 2.7 & 0.5 & 100.0 \\
\hline Elveden & 12-24 (low) & 0 & 0 & 2.3 & 0 & 0 & 31.8 & 0 & 0 & 0 & 34.1 \\
\hline \multirow[t]{4}{*}{$N=44$} & 25-36 (medium-to-low) & 2.3 & 2.3 & 13.6 & 6.8 & 4.5 & 27.3 & 0 & 2.3 & 0 & 59.1 \\
\hline & 37-48 (medium-to-high) & 0 & 0 & 0 & 2.3 & 2.3 & 0 & 0 & 2.3 & 0 & 6.8 \\
\hline & $49-60$ (high) & 0 & 0 & 0 & 0 & 0 & 0 & 0 & 0 & 0 & .0 \\
\hline & Total & 2.3 & 2.3 & 15.9 & 9.1 & 6.8 & 59.1 & 0 & 4.5 & 0 & 100.0 \\
\hline Hoxne Upper & 12-24 (low) & 0 & 0 & 0 & 0 & 0 & 4.2 & 0 & 0 & 0 & 4.2 \\
\hline Industry & 25-36 (medium-to-low) & 0 & 0 & 8.3 & 0 & 0 & 12.5 & 4.2 & 0 & 0 & 25.0 \\
\hline \multirow[t]{3}{*}{$N=24$} & 37-48 (medium-to-high) & 0 & 8.3 & 4.2 & 8.3 & 4.2 & 16.7 & 0 & 0 & 0 & 41.7 \\
\hline & 49-60 (high) & 0 & 4.2 & 0 & 0 & 4.2 & 20.8 & 0 & 0 & 0 & 29.2 \\
\hline & Total & 0 & 12.5 & 12.5 & 8.3 & 8.3 & 54.2 & 4.2 & 0 & 0 & 100.0 \\
\hline Et Tabun F & 12-24 (low) & 1.2 & 3.6 & 3.6 & 1.2 & 0 & 28.9 & 1.2 & 0 & 0 & 39.8 \\
\hline \multirow[t]{4}{*}{$N=83$} & 25-36 (medium-to-low) & 3.6 & 0 & 4.8 & 0 & 2.4 & 16.9 & 1.2 & 0 & 0 & 28.9 \\
\hline & 37-48 (medium-to-high) & 0 & 2.4 & 0 & 0 & 0 & 10.8 & 0 & 1.2 & 0 & 14.5 \\
\hline & 49-60 (high) & 1.2 & 3.6 & 2.4 & 1.2 & 0 & 7.2 & 0 & 1.2 & 0 & 16.9 \\
\hline & Total & 6.0 & 9.6 & 10.8 & 2.4 & 2.4 & 63.9 & 2.4 & 2.4 & 0 & 100.0 \\
\hline Et Tabun Ea-Ed & $12-24$ (low) & 0 & 0.6 & 2.5 & 0.4 & 0.4 & 15.3 & 0.6 & 0.2 & 0 & 19.8 \\
\hline \multirow[t]{4}{*}{$N=530$} & 25-36 (medium-to-low) & 0.9 & 4.5 & 7.7 & 1.7 & 2.1 & 14.5 & 1.5 & 0.2 & 0 & 33.2 \\
\hline & 37-48 (medium-to-high) & 1.7 & 3.0 & 7.2 & 1.1 & 0.8 & 10.8 & 0.9 & 0.2 & 0 & 25.7 \\
\hline & 49-60 (high) & 2.3 & 2.1 & 4.3 & 0.8 & 1.3 & 9.2 & 0.6 & 0.8 & 0 & 21.3 \\
\hline & Total & 4.9 & 10.2 & 21.7 & 4.0 & 4.5 & 49.8 & 3.6 & 1.3 & 0 & 100.0 \\
\hline Broom Pits & 12-24 (low) & 0.1 & 0.7 & 1.8 & 0.5 & 0.7 & 16.8 & 0.2 & 0.2 & 0 & 20.9 \\
\hline \multirow[t]{4}{*}{$N=912$} & 25-36 (medium-to-low) & 1.3 & 3.7 & 6.7 & 4.3 & 3.2 & 37.2 & 1.8 & 1.4 & 0 & 59.5 \\
\hline & 37-48 (medium-to-high) & 2.3 & 1.4 & 1.6 & 2.9 & 1.6 & 6.3 & 1.0 & 0.7 & 0 & 17.8 \\
\hline & 49-60 (high) & 0.5 & 0.4 & 0.1 & 0.3 & 0.2 & 0 & 0.1 & 0 & 0 & 1.8 \\
\hline & Total & 4.3 & 6.3 & 10.2 & 8.0 & 5.7 & 60.2 & 3.1 & 2.3 & 0 & 100.0 \\
\hline Et Tabun D & 12-24 (low) & 0 & 0 & 0 & 0 & 16.7 & 16.7 & 0 & 0 & 0 & 33.3 \\
\hline \multirow[t]{4}{*}{$N=6$} & 25-36 (medium-to-low) & 0 & 0 & 0 & 0 & 0 & 16.7 & 0 & 0 & 0 & 16.7 \\
\hline & 37-48 (medium-to-high) & 0 & 0 & 0 & 0 & 16.7 & 0 & 0 & 0 & 0 & 16.7 \\
\hline & 49-60 (high) & 0 & 0 & 16.7 & 0 & 0 & 0 & 16.7 & 0 & 0 & 33.3 \\
\hline & Total & 0 & 0 & 16.7 & 0 & 33.3 & 33.3 & 16.7 & 0 & 0 & 100.0 \\
\hline Pontnewydd & 12-24 (low) & 0 & 1.7 & 12.1 & 1.7 & 0 & 53.4 & 0 & 0 & 0 & 69.0 \\
\hline Cave & 25-36 (medium-to-low) & 1.7 & 1.7 & 5.2 & 1.7 & 0 & 19.0 & 0 & 0 & 0 & 29.3 \\
\hline \multirow[t]{3}{*}{$N=58$} & 37-48 (medium-to-high) & 0 & 0 & 1.7 & 0 & 0 & 0 & 0 & 0 & 0 & 1.7 \\
\hline & 49-60 (high) & 0 & 0 & 0 & 0 & 0 & 0 & 0 & 0 & 0 & 0 \\
\hline & Total & 1.7 & 3.4 & 19.0 & 3.4 & 0 & 72.4 & 0 & 0 & 0 & 100.0 \\
\hline Cuxton & $12-24$ (low) & 0.5 & 0.5 & 9.1 & 0.5 & 0.5 & 47.8 & 0.5 & 0.5 & 0 & 60.2 \\
\hline \multirow[t]{4}{*}{$N=186$} & 25-36 (medium-to-low) & 0.5 & 3.2 & 8.1 & 0 & 0.5 & 18.3 & 1.6 & 0.5 & 0 & 32.8 \\
\hline & 37-48 (medium-to-high) & 1.6 & 1.6 & 0 & 0 & 0.5 & 3.2 & 0 & 0 & 0 & 7.0 \\
\hline & 49-60 (high) & 0 & 0 & 0 & 0 & 0 & 0 & 0 & 0 & 0 & 0 \\
\hline & Total & 2.7 & 5.4 & 17.2 & 0.5 & 1.6 & 69.4 & 2.2 & 1.1 & 0 & 100.0 \\
\hline Lynford & 12-24 (low) & 0 & 0 & 3.9 & 3.9 & 3.9 & 33.3 & 2.0 & 2.0 & 0 & 49.0 \\
\hline $\mathrm{N}=51$ & 25-36 (medium-to-low) & 7.8 & 5.9 & 2.0 & 5.9 & 3.9 & 11.8 & 3.9 & 2.0 & 0 & 43.1 \\
\hline & 37-48 (medium-to-high) & 0 & 2.0 & 0 & 3.9 & 0 & 0 & 2.0 & 0 & 0 & 7.8 \\
\hline & 49-60 (high) & 0 & 0 & 0 & 0 & 0 & 0 & 0 & 0 & 0 & 0 \\
\hline & Total & 7.8 & 7.8 & 5.9 & 13.7 & 7.8 & 45.1 & 7.8 & 3.9 & 0 & 100.0 \\
\hline
\end{tabular}




\begin{tabular}{|c|c|c|c|c|c|c|c|c|c|c|c|}
\hline & & \multicolumn{10}{|c|}{ Symmetry by eye \% } \\
\hline & & yes,yes,yes & yes,yes,no & yes,no,no & no,yes,yes & no,no,yes & no,no,no & no,yes,no & yes,no,yes & Pdf & Total \\
\hline Cave of Hearths & 12-24 (low) & 0 & 0 & 0 & 0 & 0 & 4.9 & 0.9 & 0 & 0 & 5.8 \\
\hline \multirow[t]{4}{*}{$N=223$} & 25-36 (medium-to-low) & 0 & 2.2 & 2.7 & 1.3 & 1.3 & 20.2 & 4.5 & 0 & 0 & 32.3 \\
\hline & 37-48 (medium-to-high) & 1.3 & 1.8 & 3.1 & 0.9 & 3.6 & 25.1 & 3.6 & 0.9 & 0 & 40.4 \\
\hline & $49-60$ (high) & 1.8 & 4.9 & 2.7 & 0.9 & 0.9 & 8.5 & 0.9 & 0.9 & 0 & 21.5 \\
\hline & Total & 3.1 & 9.0 & 8.5 & 3.1 & 5.8 & 58.7 & 9.9 & 1.8 & 0 & 100.0 \\
\hline High Lodge & 12-24 (low) & 0 & 0 & 0 & 0 & 0 & 0 & 0 & 0 & 0 & 0 \\
\hline \multirow[t]{4}{*}{$N=15$} & 25-36 (medium-to-low) & 0 & 0 & 0 & 20.0 & 0 & 33.3 & 0 & 0 & 0 & 53.3 \\
\hline & 37-48 (medium-to-high) & 0 & 6.7 & 20.0 & 13.3 & 0 & 6.7 & 0 & 0 & 0 & 46.7 \\
\hline & 49-60 (high) & 0 & 0 & 0 & 0 & 0 & 0 & 0 & 0 & 0 & 0 \\
\hline & Total & 0 & 6.7 & 20.0 & 33.3 & 0 & 40.0 & 0 & 0 & 0 & 100.0 \\
\hline Warren Hill & 12-24 (low) & 0.4 & 1.1 & 2.2 & 0.7 & 0.7 & 15.1 & 0.7 & 0 & 0 & 21.0 \\
\hline \multirow[t]{4}{*}{$N=548$} & 25-36 (medium-to-low) & 4.0 & 6.8 & 6.4 & 5.5 & 6.2 & 30.8 & 2.7 & 1.5 & 0.2 & 64.1 \\
\hline & 37-48 (medium-to-high) & 2.0 & 2.6 & 1.5 & 1.8 & 1.1 & 3.6 & 0.4 & 1.3 & 0.4 & 14.6 \\
\hline & $49-60$ (high) & 0.4 & 0 & 0 & 0 & 0 & 0 & 0 & 0 & 0 & 0.4 \\
\hline & Total & 6.8 & 10.4 & 10.0 & 8.0 & 8.0 & 49.6 & 3.8 & 2.7 & 0.5 & 100.0 \\
\hline Elveden & 12-24 (low) & 0 & 0 & 2.3 & 0 & 0 & 31.8 & 0 & 0 & 0 & 34.1 \\
\hline \multirow[t]{4}{*}{$N=44$} & 25-36 (medium-to-low) & 2.3 & 2.3 & 13.6 & 6.8 & 4.5 & 27.3 & 0 & 2.3 & 0 & 59.1 \\
\hline & 37-48 (medium-to-high) & 0 & 0 & 0 & 2.3 & 2.3 & 0 & 0 & 2.3 & 0 & 6.8 \\
\hline & 49-60 (high) & 0 & 0 & 0 & 0 & 0 & 0 & 0 & 0 & 0 & .0 \\
\hline & Total & 2.3 & 2.3 & 15.9 & 9.1 & 6.8 & 59.1 & 0 & 4.5 & 0 & 100.0 \\
\hline Hoxne Upper & 12-24 (low) & 0 & 0 & 0 & 0 & 0 & 4.2 & 0 & 0 & 0 & 4.2 \\
\hline Industry & 25-36 (medium-to-low) & 0 & 0 & 8.3 & 0 & 0 & 12.5 & 4.2 & 0 & 0 & 25.0 \\
\hline \multirow[t]{3}{*}{$N=24$} & 37-48 (medium-to-high) & 0 & 8.3 & 4.2 & 8.3 & 4.2 & 16.7 & 0 & 0 & 0 & 41.7 \\
\hline & $49-60$ (high) & 0 & 4.2 & 0 & 0 & 4.2 & 20.8 & 0 & 0 & 0 & 29.2 \\
\hline & Total & 0 & 12.5 & 12.5 & 8.3 & 8.3 & 54.2 & 4.2 & 0 & 0 & 100.0 \\
\hline Et Tabun F & $12-24$ (low) & 1.2 & 3.6 & 3.6 & 1.2 & 0 & 28.9 & 1.2 & 0 & 0 & 39.8 \\
\hline \multirow[t]{4}{*}{$N=83$} & 25-36 (medium-to-low) & 3.6 & 0 & 4.8 & 0 & 2.4 & 16.9 & 1.2 & 0 & 0 & 28.9 \\
\hline & 37-48 (medium-to-high) & 0 & 2.4 & 0 & 0 & 0 & 10.8 & 0 & 1.2 & 0 & 14.5 \\
\hline & 49-60 (high) & 1.2 & 3.6 & 2.4 & 1.2 & 0 & 7.2 & 0 & 1.2 & 0 & 16.9 \\
\hline & Total & 6.0 & 9.6 & 10.8 & 2.4 & 2.4 & 63.9 & 2.4 & 2.4 & 0 & 100.0 \\
\hline Et Tabun Ea-Ed & 12-24 (low) & 0 & 0.6 & 2.5 & 0.4 & 0.4 & 15.3 & 0.6 & 0.2 & 0 & 19.8 \\
\hline \multirow[t]{4}{*}{$N=530$} & 25-36 (medium-to-low) & 0.9 & 4.5 & 7.7 & 1.7 & 2.1 & 14.5 & 1.5 & 0.2 & 0 & 33.2 \\
\hline & 37-48 (medium-to-high) & 1.7 & 3.0 & 7.2 & 1.1 & 0.8 & 10.8 & 0.9 & 0.2 & 0 & 25.7 \\
\hline & 49-60 (high) & 2.3 & 2.1 & 4.3 & 0.8 & 1.3 & 9.2 & 0.6 & 0.8 & 0 & 21.3 \\
\hline & Total & 4.9 & 10.2 & 21.7 & 4.0 & 4.5 & 49.8 & 3.6 & 1.3 & 0 & 100.0 \\
\hline Broom Pits & 12-24 (low) & 0.1 & 0.7 & 1.8 & 0.5 & 0.7 & 16.8 & 0.2 & 0.2 & 0 & 20.9 \\
\hline \multirow[t]{4}{*}{$N=912$} & 25-36 (medium-to-low) & 1.3 & 3.7 & 6.7 & 4.3 & 3.2 & 37.2 & 1.8 & 1.4 & 0 & 59.5 \\
\hline & 37-48 (medium-to-high) & 2.3 & 1.4 & 1.6 & 2.9 & 1.6 & 6.3 & 1.0 & 0.7 & 0 & 17.8 \\
\hline & $49-60$ (high) & 0.5 & 0.4 & 0.1 & 0.3 & 0.2 & 0 & 0.1 & 0 & 0 & 1.8 \\
\hline & Total & 4.3 & 6.3 & 10.2 & 8.0 & 5.7 & 60.2 & 3.1 & 2.3 & 0 & 100.0 \\
\hline Et Tabun D & 12-24 (low) & 0 & 0 & 0 & 0 & 16.7 & 16.7 & 0 & 0 & 0 & 33.3 \\
\hline \multirow[t]{4}{*}{$N=6$} & 25-36 (medium-to-low) & 0 & 0 & 0 & 0 & 0 & 16.7 & 0 & 0 & 0 & 16.7 \\
\hline & 37-48 (medium-to-high) & 0 & 0 & 0 & 0 & 16.7 & 0 & 0 & 0 & 0 & 16.7 \\
\hline & 49-60 (high) & 0 & 0 & 16.7 & 0 & 0 & 0 & 16.7 & 0 & 0 & 33.3 \\
\hline & Total & 0 & 0 & 16.7 & 0 & 33.3 & 33.3 & 16.7 & 0 & 0 & 100.0 \\
\hline Pontnewydd & 12-24 (low) & 0 & 1.7 & 12.1 & 1.7 & 0 & 53.4 & 0 & 0 & 0 & 69.0 \\
\hline Cave & 25-36 (medium-to-low) & 1.7 & 1.7 & 5.2 & 1.7 & 0 & 19.0 & 0 & 0 & 0 & 29.3 \\
\hline \multirow[t]{3}{*}{$N=58$} & 37-48 (medium-to-high) & 0 & 0 & 1.7 & 0 & 0 & 0 & 0 & 0 & 0 & 1.7 \\
\hline & 49-60 (high) & 0 & 0 & 0 & 0 & 0 & 0 & 0 & 0 & 0 & 0 \\
\hline & Total & 1.7 & 3.4 & 19.0 & 3.4 & 0 & 72.4 & 0 & 0 & 0 & 100.0 \\
\hline Cuxton & 12-24 (low) & 0.5 & 0.5 & 9.1 & 0.5 & 0.5 & 47.8 & 0.5 & 0.5 & 0 & 60.2 \\
\hline \multirow[t]{4}{*}{$N=186$} & 25-36 (medium-to-low) & 0.5 & 3.2 & 8.1 & 0 & 0.5 & 18.3 & 1.6 & 0.5 & 0 & 32.8 \\
\hline & 37-48 (medium-to-high) & 1.6 & 1.6 & 0 & 0 & 0.5 & 3.2 & 0 & 0 & 0 & 7.0 \\
\hline & 49-60 (high) & 0 & 0 & 0 & 0 & 0 & 0 & 0 & 0 & 0 & 0 \\
\hline & Total & 2.7 & 5.4 & 17.2 & 0.5 & 1.6 & 69.4 & 2.2 & 1.1 & 0 & 100.0 \\
\hline Lynford & 12-24 (low) & 0 & 0 & 3.9 & 3.9 & 3.9 & 33.3 & 2.0 & 2.0 & 0 & 49.0 \\
\hline $\mathrm{N}=51$ & 25-36 (medium-to-low) & 7.8 & 5.9 & 2.0 & 5.9 & 3.9 & 11.8 & 3.9 & 2.0 & 0 & 43.1 \\
\hline & 37-48 (medium-to-high) & 0 & 2.0 & 0 & 3.9 & 0 & 0 & 2.0 & 0 & 0 & 7.8 \\
\hline & 49-60 (high) & 0 & 0 & 0 & 0 & 0 & 0 & 0 & 0 & 0 & 0 \\
\hline & Total & 7.8 & 7.8 & 5.9 & 13.7 & 7.8 & 45.1 & 7.8 & 3.9 & 0 & 100.0 \\
\hline
\end{tabular}


Table 7. Relationship between assemblage, edge working index and tip shape. PA= Profoundly Asymmetrical.

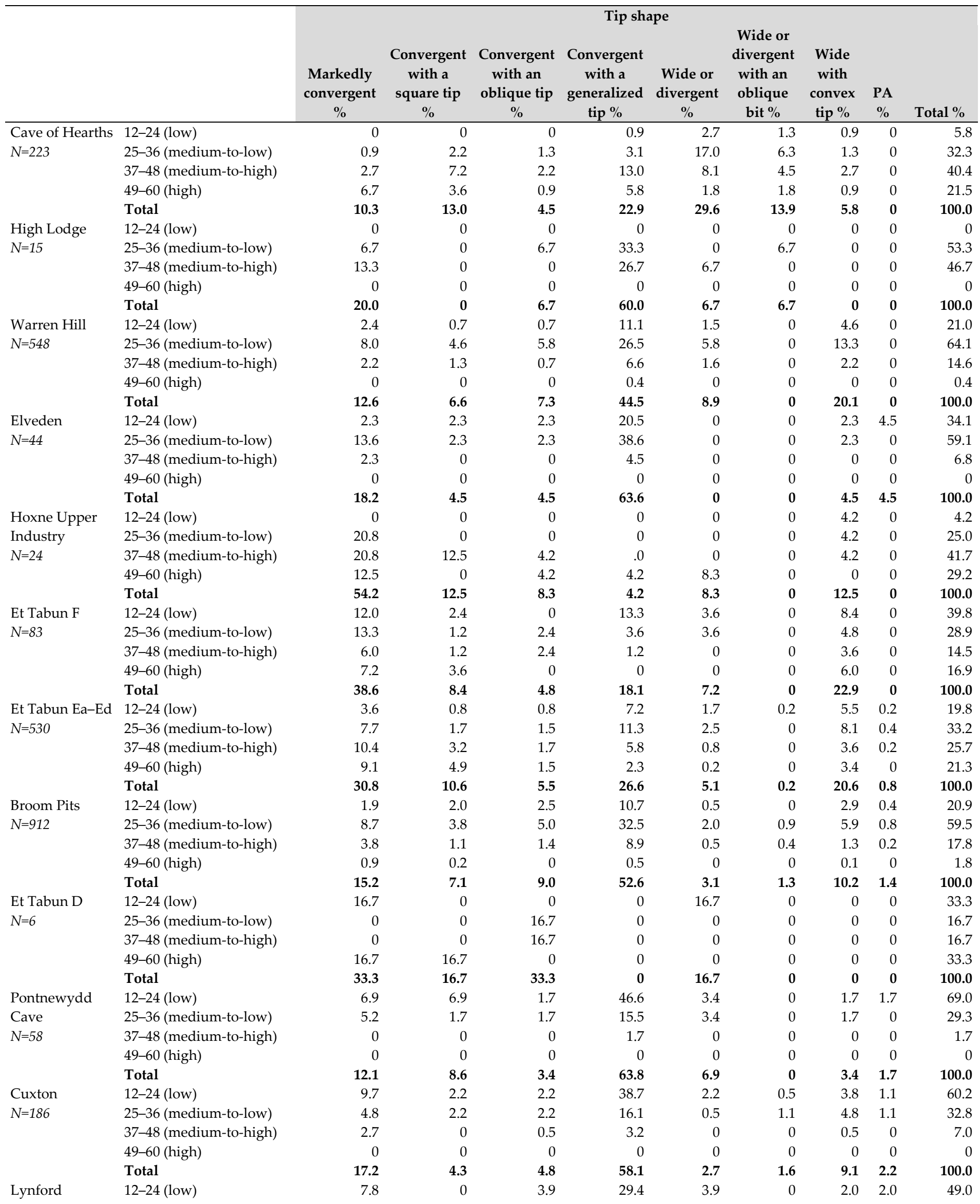




\begin{tabular}{|c|c|c|c|c|c|c|c|c|c|c|}
\hline \multirow[t]{3}{*}{$N=51$} & 25-36 (medium-to-low) & 15.7 & 3.9 & 2.0 & 21.6 & 0 & 0 & 0 & 0 & 43.1 \\
\hline & 37-48 (medium-to-high) & 3.9 & 0 & 0 & 3.9 & 0 & 0 & 0 & 0 & 7.8 \\
\hline & Total & 27.5 & 3.9 & 5.9 & 54.9 & 3.9 & 0 & 2.0 & 2.0 & 100.0 \\
\hline
\end{tabular}

\section{Total $N=2680$}




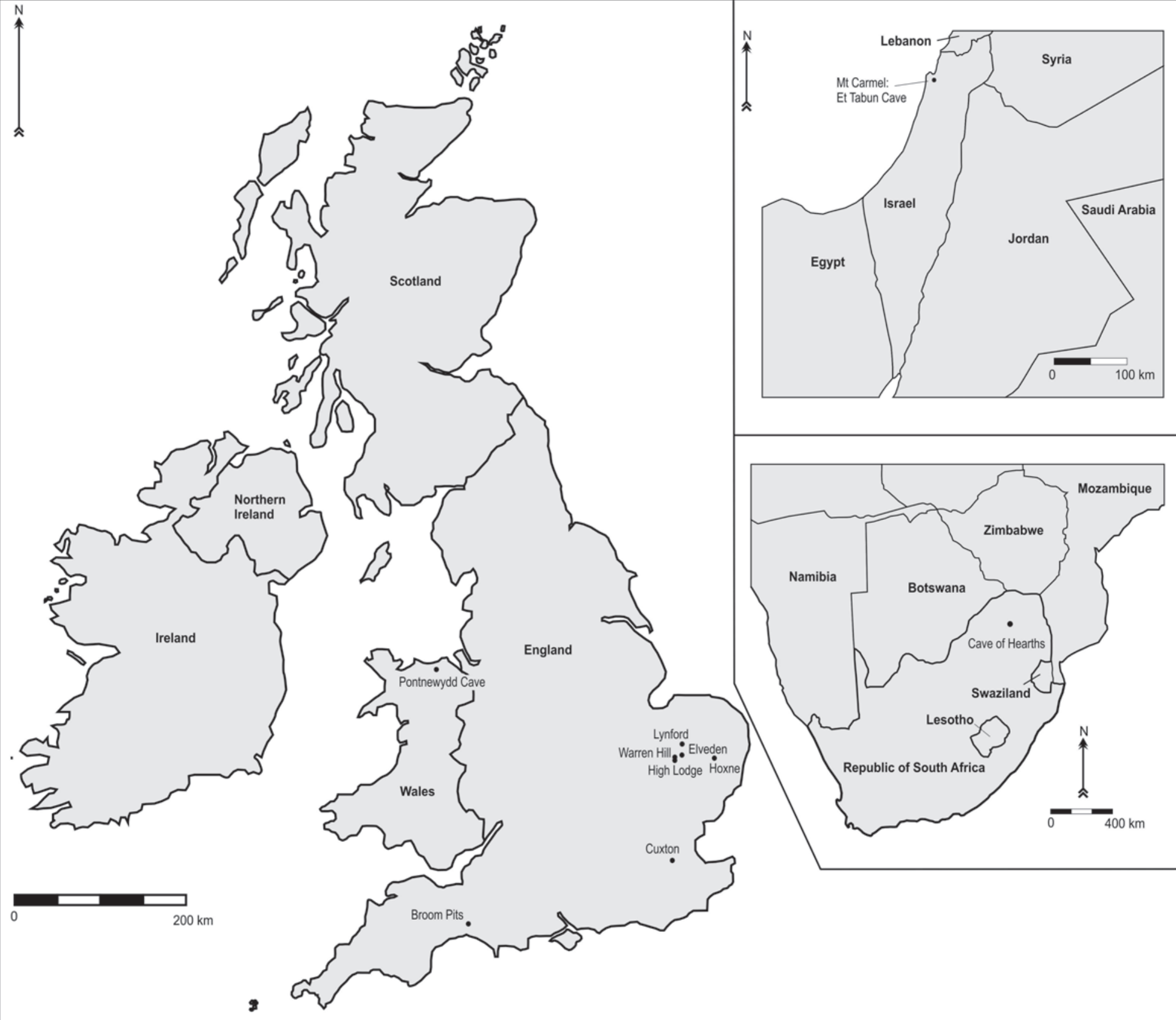




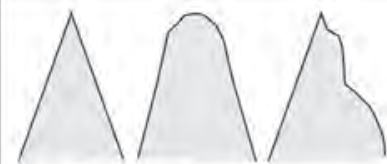

1

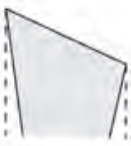

6

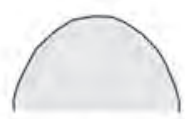

7

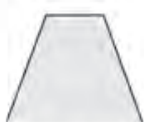

2

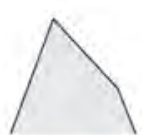

3

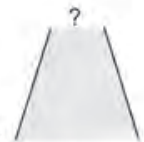

4

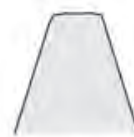

4

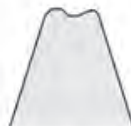

4

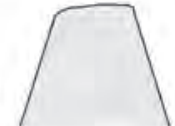

4

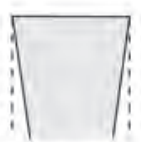

5

A: Tip shape - Illustrating examples of the seven categories of tip classification:

1: markedly convergent; 2 : convergent with a squared-off tip at right angles or nearly so; 3 : convergent with an oblique tip; 4 : convergent with a generalized tip; 5 : wide (parallel) or divergent; 6: wide or divergent with an oblique tip; 7 : wide with a very convex tip.

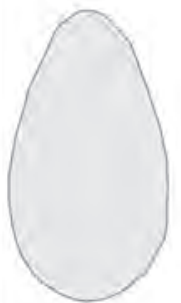

1

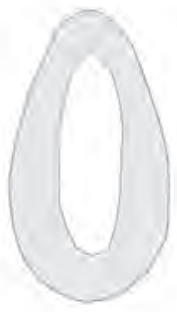

2

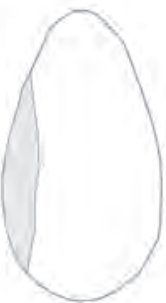

3

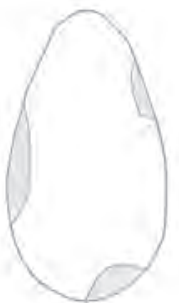

3

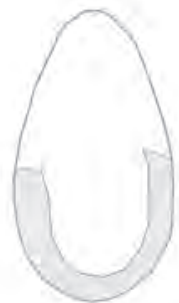

3

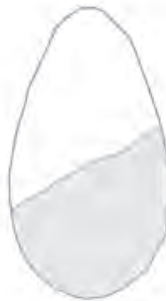

4

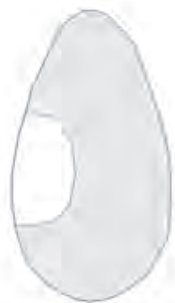

5

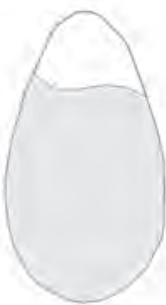

5

B: Secondary flaking - Illustrating examples of the five categories of secondary flaking extent and pattern: 1 = complete; 2 = complete marginal; 3 = partial marginal; 4 =partial; 5 = substantial.
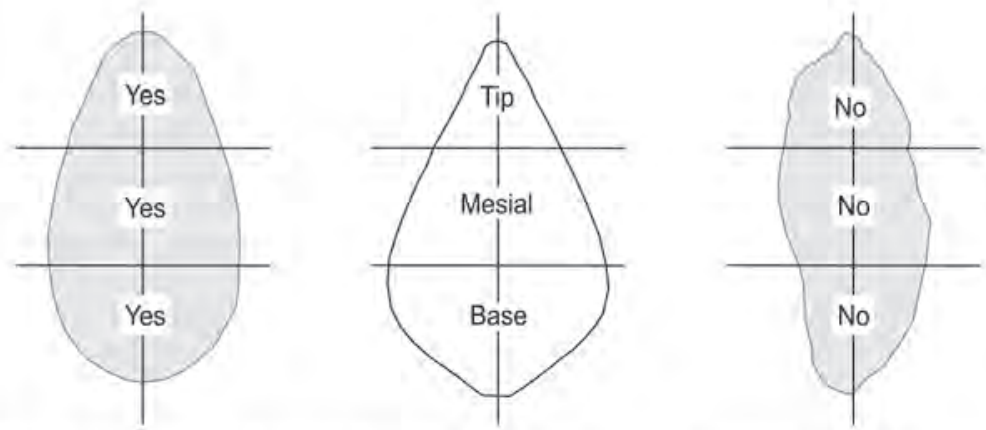

C: Symmetry - Illustrating handaxe symmetry and schema for recording. The grey handaxe outlines represent real examples from the Warren Hill assemblage stored at Frank's House, The British Museum.

\begin{tabular}{|l|l|l|l|l|l|l|l|l|}
\hline Classification & 1 & 2 & 3 & 4 & 5 & 6 & 7 & 8 \\
\hline Tip & Yes & Yes & Yes & No & No & No & No & Yes \\
\hline Mesial & Yes & Yes & No & Yes & No & No & Yes & No \\
\hline Base & Yes & No & No & Yes & Yes & No & No & Yes \\
\hline
\end{tabular}

Face 1

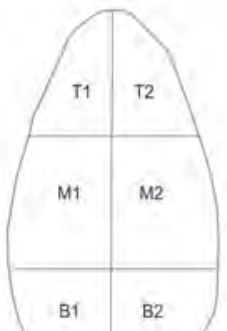

Face 2

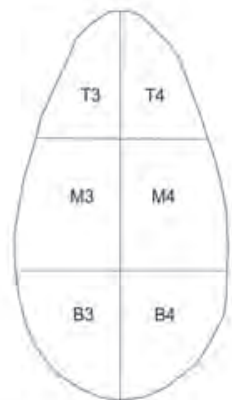

D: Edge working - Illustrating how to quantify the amount of edge working on an LCT. Cumulative values (from each section) are assigned to each face in respect to degree of edge working observed. The artefact is then given a single value, the sum of the values for the two faces to provide an index for the amount of edge working present.

\begin{tabular}{|c|c|c|c|c|}
\hline $0 \%$ & $<50 \%$ & c. $50 \%$ & $>50 \%$ & $100 \%$ \\
\hline 1 & 2 & 3 & 4 & 5 \\
\hline
\end{tabular}

